\title{
DEPRESSION AND ITS SCREENING PROGRAMS AMONG VOLUNTARY AFRICAN MIGRANTS WITHIN AFRICA. A SYSTEMATIC REVIEW
}

\author{
Shallon Atuhaire ${ }^{1 *}$ \\ Pan African University of Life and Earth Sciences, \\ University of Ibadan, Nigeria. \\ (Email: atuhaireshina@yahoo.com) \\ *Corresponding author: Shallon Atuhaire \\ (Email: shallonatuhairetaremwa@gmail.com) \\ Nkechi Martina Odogwu ${ }^{2}$ \\ Pan African University of Life and Earth Sciences, \\ University of Ibadan, Nigeria. \\ (Email: nkechiodogwu27@gmail.com)
}

Received date: 27-06-2019

Revised date: 05-08-2019

Accepted date: 07-08-2019

Published date: 12-09-2019

To cite this document: Atuhaire, S., \& Odogwu, N. M. (2019). Depression and its Screening Programs among Voluntary African Migrants within Africa. A Systematic Review. International Journal of Education, Psychology and Counseling, 4 (32), 90-107.

DOI: $10.35631 /$ IJEPC.4320010

\begin{abstract}
Intra-continental migration has increased within Africa since the late 1980s. Africa to Africa migration ranks fifth globally. This study intended to review studies and document risk factors for depression, depressive symptoms, screening programs and coping strategies among voluntary African migrants within Africa. Online databases search was done to select journal articles published between 1980 and 2018 about the topic. PubMed generated only 8 relevant studies, Google Scholar 11, African Journals Online only 1 and international websites 3 relevant ones. Based on the keywords, Cochran protocol for quality assessment and PRISMA flowchart, 16 articles were systematically reviewed. Findings indicate few studies on depression among voluntary African migrants in Africa. Migration itself is a risk factor for depression. Other factors are trauma, poverty, forced or illegal migration, acculturation, loneliness, age, family separation, changing gender roles, and first-time migrants. It presents as insomnia, anxiety and social dysfunction. Most screening programs available are client initiated. Family support systems, problem-focused or emotions focused coping strategies can lessen depression. Conclusively, depression is a common scenario among migrants whether voluntary or involuntary but screening programs targeting voluntary migrants are very rare in most African settings. Culturally relevant and appropriate approaches targeting voluntary migrants would address the issue.
\end{abstract}

Keywords: Africa, Depression, Mental Health, Migrants, Voluntary Migration 


\section{Introduction}

Africa has been labeled a "continent on the move" (Flahaux \& De Haas 2016). Africans migrate not only to developed and industrialized countries but also within the continent since the late 1980s. Migration is a risk factor for depression considering migratory policies, expectations, and acculturation (Bhugra, 2004; Vroman, 2011). Depression is a mental disorder that presents with mood swings, loss of concentration and or pleasure, diminished energy, feelings of guilt or low self-esteem and dignity, insomnia, and appetite loss (WHO 2012b). Studies on depression among African migrants have paid less attention to African migrants within Africa and those that did focused on those under forced conditions such as natural calamities, poverty, and political instabilities (Tessie 1995; Carballo \& Nerukar 2001; Pannetier, Lert, Roustide, \& Desgrees du Lou, 2017). As such, investigations on depression and its screening programs among voluntary African migrants are almost non-existent which impelled this study.

About 100 million people were migrants across the globe in the 1980s, the number continued to increase due to economic booms in various countries and by 1990, the number had increased to 150 million. At the beginning of the $21^{\text {st }}$ century, it was already 200 million people, and it has continued to increase more than ever in the history of humanity with both men and women migrating under both forced and voluntary circumstances. They travel in large numbers and to further destinations as stated by Economic Community of West African States-Sahel and West African Club/ Organisation for Economic Cooperation and Development (ECOWASSWAC/OECD) (Carballo \& Nerukar 2001; Pannetier, Lert, Roustide, \& Desgrees du Lou, 2017; ECOWAS-SWAC/OECD 2006; Adepoju A 2008) for semi-permanent or permanent periods (Bhugra, 2004). Of the 200 million migrants, 16 million were in Africa from both within the continent and overseas. Nevertheless, even under best and desirable circumstances, the process of migration is very stressful and traumatizing resulting in considerable levels of depression among migrants and their close comrades, however, its effect is greater among women and children than men (Martin 2001).

Over the years, voluntary international African migrants have migrated within the continent mainly to South Africa, Libya, Nigeria, Cote d'Ivoire, and others. Since 1960, Libya has been recruiting able-bodied men and women from Islamic states as laborers in oil industries while South Africa has been recruiting people from mainly Lesotho, Mozambique and elsewhere across the continent to work in the mines (Martin 2001). Other countries in Africa receive corporate migrants, scholars, tourists, investors, researchers, employees of international organizations, peace corps, students on internship, holidaymakers, humanitarian agencies and others as either semi-permanent or permanent residents. Despite the basis for migration, the effect of income inequalities and political instabilities common among African countries tend to affect social cohesion, which results in depression among migrants (Jurado D et al. 2017).

In the recent past, organizations such as United Nations (UN), Pan African Union (PAU), East African Community (EAC), and the Economic Community of West African States (ECOWAS) have contributed significantly to increased voluntary international immigration within Africa through regional integration strategies including sponsored education and training, employment, and delegation (ECOWAS-SWAC/OECD (2006). Voluntary migrants also, known as "economic migrants" are those whose migration process is motivated by their desires to gain better socio-economic conditions than those in their native countries. Such socioeconomic conditions among others include; employment and posting, deployment, trade, academic, marriage, and adoption (Cassidy 2005; Jurado D et al. 2017). 
Involuntary migrants, on the other hand, may migrate due to displacement by natural calamities, political instabilities, fear of getting prosecuted, coercion and or deception (Cassidy 2005). They include humanitarian migrants such as refugees, asylees, unauthorized and lawful permanent residents. No matter the circumstances of migration, its' effect on the migrant's mental health cannot be understated. These result from a change of social ties, social network reconstruction, and a drastic shift in economic and cultural systems ((Martin 2001; Issack 2015) leading to disillusionment, and depression which are of great public health importance to the health system, migrants, citizens, and the host country's image.

Although migrants may arrive in the host country in a complete state of wellbeing with feelings of euphoria, several factors may provoke and aggravate depression such as inaccessible health care due to communication barriers (Carballo \& Nerukar 2001), which eventually results in a missed opportunity for timely interventions (Newbold \& Danford 2003). Other risk factors include; change and failure to meet expectations, social segregation, financial issues, and parenting coupled with other responsibilities such as academics or employment, strict policies, conflicts, changing gender roles, communication barriers, and inability to negotiate social services. This results in varying degrees of depression or madness in some instances due to accumulated effect. The accumulated effect of depression is deeply entrenched in cultural coping strategies such as silence as people would never want to show others that they are going through hardships (Bhugra, 2004; Earlise, Sherril, \& David 2001).

The circumstances for migration whether voluntary or involuntary play a significant role in a migrant's mental health even when it is for a good cause although the level of the effect differs by gender (Adepoju 2008; Lassetter \& Callister 2008). Therefore, this study will inform and elicit public health policy and response that suit and meet the needs of voluntary migrants. Exploring and identifying screening programs that have been offering services to depressed African migrants within Africa is key to highlight existing interventions. It creates awareness of available services and how they can be accessed. This will promote treatment-seeking behaviors among depressed migrants, increase referrals and enlighten current and future clients. The study has been conceptualized as demonstrated in Figure 1.

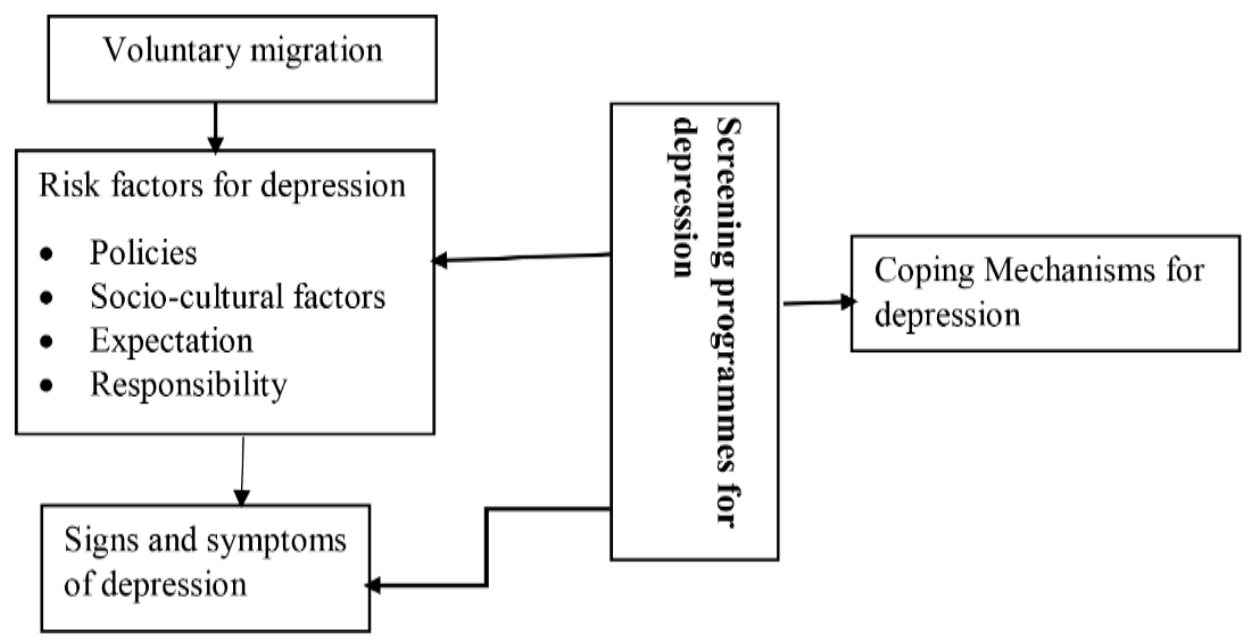

Fig. 1: Conceptual framework 


\section{Methods}

The study systematically reviewed, document and highlighted depression and access to its screening programs among voluntary African migrants. To achieve this purpose, online databases mainly PubMed, Google Scholar, African Journals Online, individualized Journals and International Organizations' published between 1980 to date were searched. The period between 1980 to date was considered to compare depressive factors in the last two decades of the $20^{\text {th }}$ Century and now; almost two decades into the $21^{\text {st }}$ century which have witnessed a greater increase in migration registering relatively similar rates between men and women due to globalization (Bhugra, 2004). Therefore, PubMed generated 15 articles, 8 of them were relevant t. Google Scholar, 8,960,000 but 11 were relevant. African Journals Online 500, with only one relevant while individualized and International Organizations' Websites generated 12 articles but only two of which by WHO, and one by [Food and Agriculture Organization (FAO)]. Only 23 articles met the selection criteria but four were duplications between Google Scholar and PubMed. Therefore, both authors read abstracts of 19 articles but according to Cochran protocol for quality assessment (Critical Appraisal Programme 2010) and PRISMA flowchart (Moher et al. 2009), only 16 articles of them met the inclusion and exclusion criteria hence were systematically reviewed as illustrated in Table 1 . The inclusion and exclusion of the reviewed literature is schematized as in PRISMA flowchart (Figure 2).

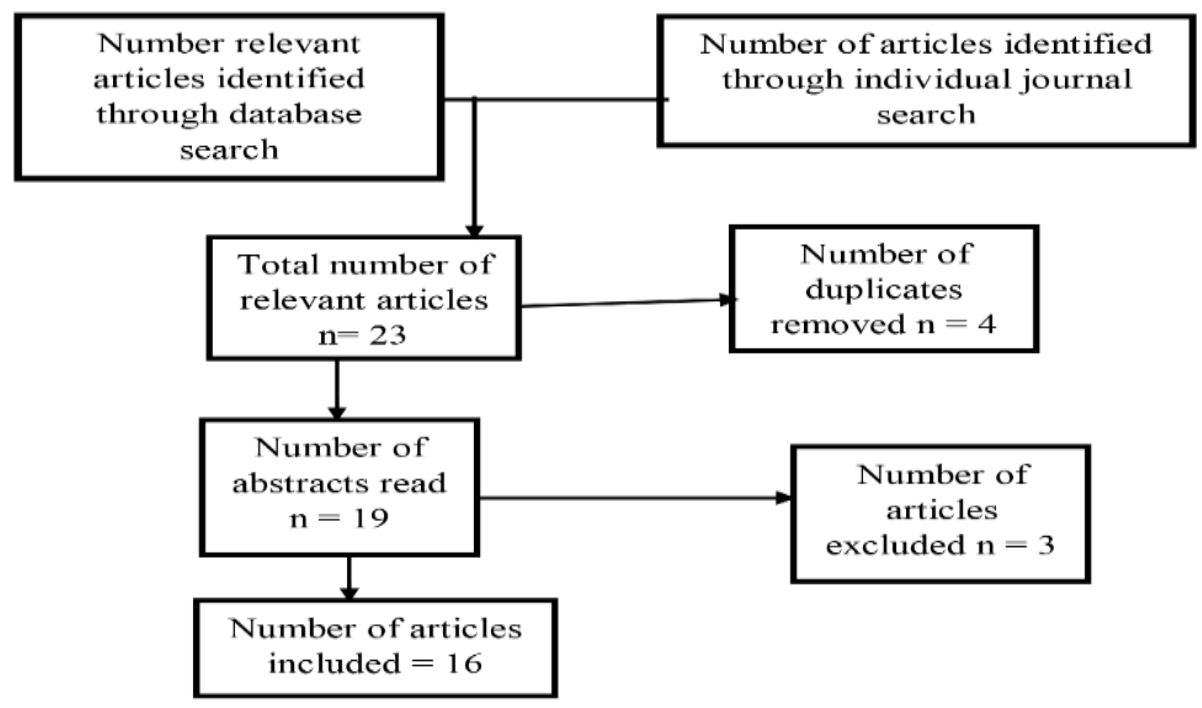

Fig. 2: PRISMA flowchart indicating selection and Inclusion of reviewed studies

\section{Review Findings}

\section{Voluntary Migrants in Africa}

Findings indicate that Africans have an extensive history of migration both within and outside the continent (FAO 2007; Baker \& Aida 1997). According to FAO (2017), Africa to Africa migration ranks fifth globally. Voluntary migration within the continent has also increased since the 1980s due to pan Africanism and globalization. Cote d'Ivoire has the highest number of immigrants in West Africa (ECOWAS-SWAC/OECD 2006), Uganda in the East (United Nations 2017), South Africa in the South (Idemudia et al. 2013), while most North African migrants transfer to Turkey, Pakistan, and Lebanon but still, Egypt receives quite a number where it generates $\$ 27$ billion per annum (Australian Institute of International Affairs 2017). Nigeria among West African countries has the greatest number of emigrants (ECOWAS- 
SWAC/OECD 2006) and Zimbabwe in the south (United Nations 2017). About 3.4 million people $(25 \%)$ of the entire population of Zimbabwe were out of the country by 2013.

Migration being a risk factor for depression like any other traditional factors such as lifestyle, health habits and risky behaviors ((Flahaux \& De Haas 2016), it does not only affect involuntary migrants who are relocating due to poverty, conflicts or environmental hazards but also voluntary migrants (Lassetter \& Callister 2008). Voluntary migrants experience both good and poor health that can be measured by their life expectancy, mortality rates, birth outcomes, morbidities, and depression (Lassetter \& Callister 2008; Maina, Mauri, \& Rossi 2016). Like voluntary migrants, involuntary migrants who are skilled and educated, are more likely to settle easily in a host country since they are aware of settlement procedures. Still, migrants and minority ethnic groups in any country suffer more from depressive symptoms compared to natives (Close et al. 2016; Rogge 2013).

\section{Risk Factors for Depression}

Although voluntary migrants are normally among the healthiest group of their native population, a condition referred to as "healthy migrant effect" (Vroman, Knoetze, \& Kagee 2011; Tessie 1995; Close et al. 2016; Lassetter \& Callister 2008), their health deteriorates soon after migration due to both pre and post migration stressors that engender depression. Studies show that its effect is carried forward to subsequent generations. Migratory policies, the nature of work, the neighborhood, racialization, and environmental factors have a significant impact on migrants' wellbeing (Viruell-Fuentes, Miranda \& Abdulrahim 2011).

Migrants with higher levels of income are more resilient to depression and post-traumatic stressors than those whose income is low (Thela et al. 2017). A study carried out in Sudan in 1986 among refugees indicated that family separation was 4.0 times more likely to cause mental illness among migrants at a confidence interval of 95\% (CI: 1.3-11.8). Post-traumatic stress was 5.2 more associated with mental health including depression than other risk factors for mental health at $95 \%$ (CI: 1.7-15.9), also anxiety was common among elderly groups of people at an adjusted odds ratio of 5.3, (95\% CI: 1.4-19.8) (Rogge 2013). According to Rogge (2013), migrants especially refugees are more likely to feel disappointed and suffer from severe depression when their applications for settlement face rejected. Also, refugees who have been exposed to pre-migration life threats such as sexual abuse, poverty, as well as post-migration stressors such as sexual abuse, and poverty were more like to suffer severe depression than migrants who had not been exposed to such (Idemudia et a. 2013).

The factors that may trigger depression symptoms may have started way back before they traveled, and these are called pre-migration stressors/trauma or later after arrival into the host country hence post-migration trauma (Adepoju 2008; Cassidy 2005). Post-migration factors may occur soon after arrival due to enduring obstacles related to settlement or later when the primary motive/s is/are not attained. Risk factors are; cultural shock, aggravated policies, and laws that govern migration, efforts to change cultural identity, living conditions of the country, which may be far different from the migrant's expectations as well as restricted family reunification in some instances (Earlise, Sherril, \& David 2001; Williams et al. 2007). Though restricted family reunion among migrant couples and families may result in depression, the marrieds generally experience less depressive situations due to the affection and emotional stability they gain from each other. At the same time, in the case of domestic violence and dissolution of marriage, social networks may be affected and one's image assaulted which leads to severe depression among married couples (Kesser \& Marilyn 1982). Supernatural, 
environmental and biological factors may cause mental illness (Issack S 2015). Besides, migrants are concerned about their inability to communicate which greatly affects their capability to seek medical services and getting the necessary information at the early stages of depression (Ochieng 2017).

A study done in East London in 1998 among migrants of different origins including first generation Somali migrants, found out that physical health issues, inappropriate housing conditions, inadequate community services, and family support were significantly associated with depression (Silviera \& Ebrahim 1998). The moral obligation to offer financial support to family members left behind may result in depression if not met (Earlise, Sherril, \& David 2001).

The effect of cultural displacement, racism, language barrier, housing and settlement, expectations, minority status, decreased socio-economic support from family members, incapacitation to negotiate various social amenities such as education, employment, and health insurance is immense moreover it affects women more than men due to holistic and swift change in gender (Issack 2015; Silviera \& Ebrahim 1998). In a study done by Schmied, V. et al. (2017), women reported this effect to be related to their position as migrants and being women who live under poor socio-economic conditions, trying hard to keep up with trends and communal standards and facing difficulties in accessing suitable services.

In the process of adopting to the new culture of the host country through language acquisition, gaining citizenship status, and social construction, migrants' health is affected (Viruell-Fuentes, Miranda, \& Abdulrahim 2011). Nonetheless, time allows them to adopt to the weather, food, behavior, norms, and attitudes of the natives (Maharaj et al. 2017).

\section{Signs and Symptoms of Depression}

Voluntary or involuntary migrants may not necessarily exhibit similar symptoms and signs of depression but the common ones include anxiety mainly among the elderly groups of people on arrival to the host country and during the first few days (Idemudia et al. 2013) Other signs and symptoms include; insomnia, social dysfunction, mood swings, and life dissatisfaction. Drug abuse among migrants also reflects depression and stress, and its' patterns may be similar to that of the natives (Silviera \& Ebrahim 1998).

The signs and symptoms of depression can still be associated with underlying illness whereas, in elderly people, pancreatic cancer may also manifest. If not diagnosed and treated early, it may lead to sadness, emptiness, and irritable mood (WHO 2012b). The risk factors and depressive symptoms are presented in Table 1.

\section{Screening Programs for Depression}

Several migrants are reluctant to seek help for depression due to the associated stigma, lack of awareness about where to seek help, illiteracy on mental health, and financial implication. Such delay in seeking help has been found to result in severe depression, which manifests as madness (McCann et al. 2016). Migrants may underutilize health services in the host countries because they have less access to family doctors, consultants, preventive health services and culturally accepted approaches (Chen \& Kazanjian 2005).

Most service providers follow the Diagnostic and Statistical Manual of Mental Disorders (DSM-5). The manual relies on patient symptoms to diagnose through a two-stage phase approach; the first considers psychological examination and self-reported signs and symptoms. 
The second correlates the symptoms and signs to medical conditions, the use of pharmacological drugs and or substance abuse to ascertain the actual condition (Maina, Mauri, \& Rossi 2016). Therefore, the DSM-5 can be introduced into projects and programs that target voluntary migrants in Africa to address issues of anxiety and depression among them. Such services can be obtained in health care units, counseling centers, and religious communities play a significant role in proving both emotion-focused and problem-focused coping strategies.

\section{Coping Strategies for Depression}

Coping is a common phrase in psychology specifically in guidance and counseling. It refers to an individual's behavioral, and cognitive, appraisal and consistent efforts to manage both intrinsic and extrinsic environment transactions (Lazarus \& Folkman 1984). In the process of copying, individuals may actively deal with stressful situations, this is known as problemfocused coping strategies. They may also pay attention to their own emotions and try as much as they can to avoid stressful situations through hanging around loved ones, family members, church members, neighbors, fictive kin and mentors; this is known as emotion-focused coping strategies. The problem-focused coping approach requires constructive behavior and actions that divert or distract situations that would eventually lead to depression. Such actions could be indulging in sports, and if already depressed one can seek counseling and take part in spiritual sessions Clients may also visit family physicians, psychiatrists, or any other healthcare providers (Issack 2015).

The role played by the family in offering social support cannot be understated. With regular video, audio calls, and texts, migrants can cope with loneliness and the feeling of isolation. With such close contact with their children, parents, spouses, relatives, and friends, they gain and feel a sense of belonging (Pannetier et al.2017; Issack 2015; Williams et al.2007; ViruellFuentes \& Schulz 2009). A new pattern of spousal migration where women migrate to their partners' host countries compared to their male counterparts has been documented. However, host countries need to design maternal mental health strategies alongside mental health services to meet their psychological needs (Latif Z 2014; WHO (2012a).

Also, community-based support systems, building trust and assuring confidentiality to the depressed party can aid reduce the degree of depression. The availability and affordability of perceived expertise in mental health coupled with the creation of awareness can increase accessibility and improve migrants' mental wellbeing (McCann et al. 2016). Spiritual wellbeing has been largely mentioned by several studies as a natural coping mechanism of depression commonly applied by African migrants (Issack S 2015).

Patients who seek medical care may be initiated on either antidepressants, psychotherapy, or combined antidepressant and psychotherapy. However, if it persists and becomes resistant to the initial treatment, then electroconvulsive therapy, transcranial magnetic stimulant, deep brain stimulation, and vagal nerve stimulation may be used. In addition, communication on adherence and behavioral change, health education, dose optimization, outreach and follow up are necessary (Maina, Mauri, \& Rossi 2016). The screening programs and coping strategies are presented in Table 1. 
Table 1: Metadata on Risk Factors for Depression, Sign and Symptoms, Screening Programs and Coping Strategies among African Migrants in Africa

\begin{tabular}{|c|c|c|c|c|c|c|c|}
\hline Author & Aim & $\begin{array}{l}\text { Study } \\
\text { population }\end{array}$ & $\begin{array}{l}\text { Study } \\
\text { site }\end{array}$ & $\begin{array}{l}\text { Risk } \\
\text { factors for } \\
\text { depression }\end{array}$ & $\begin{array}{l}\text { Signs and } \\
\text { symptoms } \\
\text { of } \\
\text { depression }\end{array}$ & $\begin{array}{l}\text { Screening } \\
\text { program } \\
\text { for } \\
\text { depression } \\
\end{array}$ & $\begin{array}{l}\text { Coping } \\
\text { strategies for } \\
\text { depression }\end{array}$ \\
\hline $\begin{array}{l}\text { Flahaux } \\
\text { ML et al } \\
(2016)\end{array}$ & $\begin{array}{l}\text { To explore the } \\
\text { evolution and } \\
\text { drivers of } \\
\text { migration } \\
\text { within, towards, } \\
\text { and from Africa } \\
\text { in the post- } \\
\text { colonial period }\end{array}$ & Africans & Africa & None & None & None & None \\
\hline $\begin{array}{l}\text { Bhugra } \\
\text { D et al. } \\
(2016)\end{array}$ & $\begin{array}{l}\text { To review the } \\
\text { literature and } \\
\text { suggest various } \\
\text { vulnerability } \\
\text { factors including } \\
\text { culture shock, } \\
\text { changed cultural } \\
\text { identity, and } \\
\text { how they play a } \\
\text { role in the } \\
\text { genesis of } \\
\text { depression }\end{array}$ & $\begin{array}{l}\text { Migrants } \\
\text { and ethnic } \\
\text { minorities }\end{array}$ & None & $\begin{array}{l}\text { Pre- } \\
\text { migration } \\
\text { biological } \\
\text { and } \\
\text { physiologic } \\
\text { al, social } \\
\text { skills } \\
\text { deficit, } \\
\text { forced } \\
\text { migration } \\
\text { and } \\
\text { persecution } \\
\text { Migration }\end{array}$ & $\begin{array}{l}\text { Stress, guilt, } \\
\text { shame, loss } \\
\text { of libido }\end{array}$ & None & None \\
\hline $\begin{array}{l}\text { Tessier K } \\
\text { (1995) }\end{array}$ & $\begin{array}{l}\text { To determine } \\
\text { challenges of } \\
\text { immigration } \\
\text { policy in the } \\
\text { New South } \\
\text { Africa }\end{array}$ & $\begin{array}{l}\text { Migrants } \\
\text { and } \\
\text { refugees }\end{array}$ & $\begin{array}{l}\text { South } \\
\text { Africa }\end{array}$ & $\begin{array}{l}\text { Immigration } \\
\text { issues }\end{array}$ & None & None & None \\
\hline $\begin{array}{l}\text { Carballo } \\
\text { M et al. } \\
(2001)\end{array}$ & $\begin{array}{l}\text { To explore } \\
\text { migration, how } \\
\text { it affects } \\
\text { refugees, and the } \\
\text { health risks } \\
\text { involved }\end{array}$ & $\begin{array}{l}\text { Migrants } \\
\text { and } \\
\text { refugees }\end{array}$ & $\begin{array}{l}\text { Europea } \\
\mathrm{n} \\
\text { countries }\end{array}$ & $\begin{array}{l}\text { Push factors } \\
\text { such as } \\
\text { poverty, } \\
\text { pull factors } \\
\text { such as } \\
\text { improved } \\
\text { standards of } \\
\text { living, } \\
\text { HIV/AIDS, } \\
\text { Hepatitis B., } \\
\text { family } \\
\text { separation, } \\
\text { social }\end{array}$ & Drug abuse & $\begin{array}{l}\text { Methadone } \\
\text { bus } \\
\text { outreach } \\
\text { program }\end{array}$ & $\begin{array}{l}\text { Settlement } \\
\text { policy on } \\
\text { mainstream } \\
\text { society } \\
\text { reintegration }\end{array}$ \\
\hline
\end{tabular}




\begin{tabular}{|c|c|c|c|c|c|c|c|}
\hline & & & & $\begin{array}{l}\text { reintegratio } \\
\text { n } \\
\text { (acculturati } \\
\text { on), } \\
\text { establishing } \\
\text { social } \\
\text { networks, } \\
\text { barriers to } \\
\text { communicat } \\
\text { e }\end{array}$ & & & \\
\hline $\begin{array}{l}\text { Pannetier } \\
\mathrm{J} \text { et al. } \\
\text { (2017) }\end{array}$ & $\begin{array}{l}\text { To understand } \\
\text { the gendered } \\
\text { roles of } \\
\text { migration paths } \\
\text { and } \\
\text { transnational ties } \\
\text { in mental health } \\
\text { among sub- } \\
\text { Saharan African } \\
\text { migrants } \\
\text { residing in the } \\
\text { Paris, France, } \\
\text { metropolitan } \\
\text { area. }\end{array}$ & $\begin{array}{l}\text { Sub- } \\
\text { Saharan } \\
\text { African }\end{array}$ & $\begin{array}{l}\text { Paris, } \\
\text { France }\end{array}$ & $\begin{array}{l}\text { Pre and post } \\
\text { migration } \\
\text { stressors, } \\
\text { transitional } \\
\text { ties, social } \\
\text { demographi } \\
\text { c factors } \\
\text { such as age } \\
\text { at } \\
\text { migration, } \\
\text { occupationa } \\
1 \text { status, and } \\
\text { life events } \\
\text { such as } \\
\text { forced } \\
\text { sexual } \\
\text { intercourse } \\
\text { and } \\
\text { homelessne } \\
\text { ss. }\end{array}$ & $\begin{array}{l}\text { Pre and post } \\
\text { migration } \\
\text { stressors, } \\
\text { transitional } \\
\text { ties, social } \\
\text { demographi } \\
\text { c factors } \\
\text { such as age } \\
\text { at } \\
\text { migration, } \\
\text { occupationa } \\
1 \text { status, and } \\
\text { life events } \\
\text { such as } \\
\text { forced } \\
\text { sexual } \\
\text { intercourse } \\
\text { and } \\
\text { homelessne } \\
\text { ss. }\end{array}$ & None & None \\
\hline $\begin{array}{l}\text { Adepoju } \\
\text { A (2008) }\end{array}$ & $\begin{array}{l}\text { To determine the } \\
\text { linkages } \\
\text { between internal } \\
\text { and international } \\
\text { migration in } \\
\text { Africa }\end{array}$ & Africans & Africa & None & None & None & None \\
\hline $\begin{array}{l}\text { JuradoD } \\
\text { et al. } \\
\text { (2017) }\end{array}$ & $\begin{array}{l}\text { To } \\
\text { systematically } \\
\text { review factors } \\
\text { associated with } \\
\text { the presence of } \\
\text { psychological } \\
\text { distress or } \\
\text { common mental } \\
\text { disorders in } \\
\text { migrant } \\
\text { populations }\end{array}$ & $\begin{array}{l}\text { Migrant } \\
\text { population }\end{array}$ & $\begin{array}{l}\text { Across } \\
\text { the globe }\end{array}$ & $\begin{array}{l}\text { Socio- } \\
\text { demographi } \\
\text { c, traumatic } \\
\text { events prior } \\
\text { to } \\
\text { migration, } \\
\text { forced, } \\
\text { unplanned, } \\
\text { poorly } \\
\text { planned or } \\
\text { illegal }\end{array}$ & $\begin{array}{l}\text { Psychologic } \\
\text { al distress or } \\
\text { common } \\
\text { mental } \\
\text { disorders }\end{array}$ & None & $\begin{array}{l}\text { Taking into } \\
\text { account of } \\
\text { risks of } \\
\text { psychiatric } \\
\text { morbidity, } \\
\text { increasing } \\
\text { language } \\
\text { proficiency, } \\
\text { family } \\
\text { reunification, }\end{array}$ \\
\hline
\end{tabular}




\begin{tabular}{|c|c|c|c|c|c|c|c|}
\hline & & & & $\begin{array}{l}\text { migration, } \\
\text { low level of } \\
\text { acculturatio } \\
\mathrm{n} \text {, living } \\
\text { alone or } \\
\text { separated } \\
\text { from family } \\
\text { in the host } \\
\text { country, } \\
\text { lack of } \\
\text { social } \\
\text { support, } \\
\text { perceived } \\
\text { discriminati } \\
\text { on, and the } \\
\text { length of } \\
\text { migrants' } \\
\text { residence in } \\
\text { the host } \\
\text { country }\end{array}$ & & & $\begin{array}{l}\text { and perceived } \\
\text { social support }\end{array}$ \\
\hline $\begin{array}{l}\text { Issack S } \\
(2015)\end{array}$ & $\begin{array}{l}\text { To determine } \\
\text { mental health- } \\
\text { seeking behavior } \\
\text { among African } \\
\text { migrants }\end{array}$ & $\begin{array}{l}\text { African } \\
\text { migrants }\end{array}$ & $\begin{array}{l}\text { Ottawa, } \\
\text { Ontario }\end{array}$ & $\begin{array}{l}\text { Pre- } \\
\text { migration } \\
\text { factors such } \\
\text { as war, } \\
\text { famine, } \\
\text { family } \\
\text { separation, } \\
\text { unemploym } \\
\text { ent, low } \\
\text { income }\end{array}$ & $\begin{array}{l}\text { Poorer self- } \\
\text { rated health, } \\
\text { low self- } \\
\text { esteem, } \\
\text { anxiety, } \\
\text { acculturativ } \\
\text { e stress, lack } \\
\text { of family } \\
\text { and social } \\
\text { support } \\
\text { network, } \\
\text { biological, } \\
\text { environmen } \\
\text { tal, } \\
\text { headache, } \\
\text { supernatural } \\
\text { crying, } \\
\text { increased } \\
\text { pulse rate, } \\
\text { tense } \\
\text { feeling, } \\
\text { insomnia }\end{array}$ & $\begin{array}{l}\text { Counseling } \\
\text { centers, } \\
\text { Religious } \\
\text { communitie } \\
\text { s }\end{array}$ & $\begin{array}{l}\text { Positive } \\
\text { coping } \\
\text { strategies, } \\
\text { which } \\
\text { include; } \\
\text { emotion- } \\
\text { focused such } \\
\text { as emotional } \\
\text { symptomatol } \\
\text { ogy, family } \\
\text { and friends, } \\
\text { positive self- } \\
\text { talk, self- } \\
\text { isolation, and } \\
\text { preventing } \\
\text { family } \\
\text { worries. } \\
\text { Problem- } \\
\text { focused such } \\
\text { as diversion } \\
\text { of s the } \\
\text { stressors, } \\
\text { spirituality, } \\
\text { and } \\
\text { counseling }\end{array}$ \\
\hline
\end{tabular}




\begin{tabular}{|c|c|c|c|c|c|c|c|}
\hline $\begin{array}{l}\text { Lassetter } \\
\text { HJ et al. } \\
(2008)\end{array}$ & $\begin{array}{l}\text { To review the } \\
\text { literature on the } \\
\text { health } \\
\text { voluntary } \\
\text { migrants to } \\
\text { Western } \\
\text { societies and } \\
\text { factors affecting } \\
\text { their health }\end{array}$ & $\begin{array}{l}\text { Voluntary } \\
\text { migrants }\end{array}$ & $\begin{array}{l}\text { Western } \\
\text { societies }\end{array}$ & Migration & $\begin{array}{l}\text { Length of } \\
\text { residence } \\
\text { and } \\
\text { acculturatio } \\
\text { n, disease } \\
\text { exposure, } \\
\text { lifestyle and } \\
\text { living } \\
\text { conditions, } \\
\text { risky } \\
\text { behaviors, } \\
\text { healthy } \\
\text { habits, } \\
\text { social } \\
\text { support } \\
\text { networks, } \\
\text { cultural and } \\
\text { linguistic } \\
\text { barriers, } \\
\text { experiences } \\
\text { with racism, } \\
\text { and levels of } \\
\text { awareness } \\
\text { of cultural } \\
\text { health } \\
\text { practices } \\
\text { among } \\
\text { health care } \\
\text { providers }\end{array}$ & $\begin{array}{l}\text { Routine } \\
\text { assessment }\end{array}$ & $\begin{array}{l}\text { Health } \\
\text { policies that } \\
\text { ensure equity } \\
\text { for migrants, } \\
\text { culturally } \\
\text { appropriate } \\
\text { health } \\
\text { promotion, } \\
\text { and routine } \\
\text { assessment of } \\
\text { migration } \\
\text { history, and } \\
\text { cultural } \\
\text { health } \\
\text { practices }\end{array}$ \\
\hline $\begin{array}{l}\text { Close C } \\
\text { et al. } \\
(2016) \text {. }\end{array}$ & $\begin{array}{l}\text { To } \\
\text { systematically } \\
\text { review and } \\
\text { synthesize all } \\
\text { reviews on the } \\
\text { mental health of } \\
\text { first-generation } \\
\text { migrants to } \\
\text { appraise the risk } \\
\text { factors for, and } \\
\text { explain } \\
\text { differences in, } \\
\text { the mental health } \\
\text { of this } \\
\text { population }\end{array}$ & Generalized & None & $\begin{array}{l}\text { First } \\
\text { generation } \\
\text { migrants, } \\
\text { experiences, } \\
\text { political, } \\
\text { geographica } \\
\text { 1, } \\
\text { psychosocia } \\
1, \\
\text { demographi } \\
\text { c and } \\
\text { occupationa } \\
1 \text { factors }\end{array}$ & $\begin{array}{l}\text { Panic, } \\
\text { agoraphobia } \\
\text {, social } \\
\text { anxiety, } \\
\text { obsessive- } \\
\text { compulsive } \\
\text { disorder, } \\
\text { specific } \\
\text { phobias, } \\
\text { trauma }\end{array}$ & None & $\begin{array}{l}\text { Reduce } \\
\text { barriers to } \\
\text { treatment } \\
\text { access. } \\
\text { Creation of } \\
\text { awareness of } \\
\text { available } \\
\text { services }\end{array}$ \\
\hline $\begin{array}{l}\text { FAO } \\
(2017)\end{array}$ & $\begin{array}{lr}\text { To provide } \\
\text { evidence } \\
\text { internal on } \\
\end{array}$ & Africans & Africa & $\begin{array}{l}\text { Rural } \\
\text { residence, } \\
\text { poverty, }\end{array}$ & $\begin{array}{l}\text { Outcome of } \\
\text { distress }\end{array}$ & None & None \\
\hline
\end{tabular}




\begin{tabular}{|c|c|c|c|c|c|c|c|}
\hline & $\begin{array}{l}\text { international } \\
\text { migration } \\
\text { patterns in } \\
\text { selected African } \\
\text { countries }\end{array}$ & & & $\begin{array}{l}\text { climate } \\
\text { change, } \\
\text { food } \\
\text { insecurity, } \\
\text { limited } \\
\text { availability } \\
\text { of decent } \\
\text { job } \\
\text { opportunitie } \\
\text { s }\end{array}$ & & & \\
\hline $\begin{array}{l}\text { Thela L } \\
\text { et al. } \\
(2017)\end{array}$ & $\begin{array}{l}\text { To investigate } \\
\text { post- } \\
\text { resettlement } \\
\text { adaptation and } \\
\text { mental health } \\
\text { challenges of } \\
\text { African } \\
\text { refugees/migrant } \\
\text { s in Durban, } \\
\text { South Africa }\end{array}$ & $\begin{array}{l}\text { African } \\
\text { refugees/mi } \\
\text { grants }\end{array}$ & $\begin{array}{l}\text { Durban, } \\
\text { South } \\
\text { Africa }\end{array}$ & $\begin{array}{l}\text { Socio- } \\
\text { demographi } \\
\text { c } \\
\text { characteristi } \\
\text { cs such as } \\
\text { age on } \\
\text { arrival and } \\
\text { marital } \\
\text { status, post- } \\
\text { migration } \\
\text { experiences, } \\
\text { post- } \\
\text { traumatic } \\
\text { stress, } \\
\text { separation, } \\
\text { length of } \\
\text { stay }\end{array}$ & None & None & None \\
\hline $\begin{array}{l}\text { Idemudia } \\
\text { ES et al. } \\
(2013)\end{array}$ & $\begin{array}{l}\text { To examines the } \\
\text { impact of trauma } \\
\text { exposures (pre- } \\
\text { and post- } \\
\text { migration } \\
\text { stressors and } \\
\text { poor mental } \\
\text { health) on } \\
\text { posttraumatic } \\
\text { stress disorder } \\
\text { (PTSD) among } \\
\text { homeless } \\
\text { Zimbabwean } \\
\text { refugees living } \\
\text { in South Africa }\end{array}$ & $\begin{array}{l}\text { Zimbabwea } \\
n \text { refugees }\end{array}$ & $\begin{array}{l}\text { Limpopo } \\
\text { South } \\
\text { Africa }\end{array}$ & $\begin{array}{l}\text { Pre and post } \\
\text { migration } \\
\text { stressors, } \\
\text { pre- } \\
\text { migration } \\
\text { life- } \\
\text { threatening } \\
\text { situations, } \\
\text { pre- } \\
\text { migration } \\
\text { sex abuse, } \\
\text { pre-poverty, } \\
\text { post } \\
\text { migration } \\
\text { sex abuse, } \\
\text { and post- } \\
\text { poverty }\end{array}$ & $\begin{array}{l}\text { Anxiety, } \\
\text { insomnia, } \\
\text { social } \\
\text { dysfunction }\end{array}$ & $\begin{array}{l}\text { Culturally } \\
\text { appropriate } \\
\text { screening } \\
\text { programs }\end{array}$ & None \\
\hline $\begin{array}{l}\text { Maina G } \\
\text { et al. } \\
(2016)\end{array}$ & $\begin{array}{l}\text { To provide an } \\
\text { overview of the } \\
\text { main depressive }\end{array}$ & None & None & $\begin{array}{l}\text { Physical } \\
\text { diseases } \\
\text { neurological }\end{array}$ & $\begin{array}{l}\text { Loss of } \\
\text { appetite, } \\
\text { fatigue, }\end{array}$ & $\begin{array}{l}\text { Diagnostic } \\
\text { and } \\
\text { Statistical }\end{array}$ & $\begin{array}{lr}\text { Use } & \text { of } \\
\text { antidepressan } \\
\text { ts } \quad \text { alone, }\end{array}$ \\
\hline
\end{tabular}




\begin{tabular}{|c|c|c|c|c|c|c|c|}
\hline & $\begin{array}{l}\text { and anxiety } \\
\text { disorders } \\
\text { according to the } \\
\text { classification of } \\
\text { the DSM-5 and } \\
\text { to present the } \\
\text { primary pharmacological } \\
\text { phan non- } \\
\text { and pharmacological } \\
\text { treatments, with } \\
\text { particular } \\
\text { emphasis on the } \\
\text { problem of } \\
\text { compliance }\end{array}$ & & & $\begin{array}{l}\text { or endocrine } \\
\text { disorder, } \\
\text { pharmacolo } \\
\text { gical } \\
\text { treatment, } \\
\text { psychoactiv } \\
\text { e drug or its } \\
\text { discontinuat } \\
\text { ion, drug } \\
\text { abuse, }\end{array}$ & $\begin{array}{l}\text { being } \\
\text { moody (sad, } \\
\text { empty, } \\
\text { irritable, } \\
\text { loss of } \\
\text { interest), } \\
\text { pancreatic } \\
\text { cancer in } \\
\text { elderly } \\
\text { migrants, } \\
\text { anxiety, } \\
\text { restlessness, }\end{array}$ & $\begin{array}{l}\text { Manual of } \\
\text { Mental } \\
\text { Disorders } \\
\text { (DSM-5). }\end{array}$ & $\begin{array}{l}\text { psychotherap } \\
\text { y alone, } \\
\text { combined } \\
\text { anti- } \\
\text { depressant/ps } \\
\text { ychotherapy, } \\
\text { electroconvul } \\
\text { sive therapy, } \\
\text { transcranial } \\
\text { magnetic } \\
\text { stimulant, } \\
\text { vagal nerve } \\
\text { stimulation, } \\
\text { deep brain } \\
\text { stimulation, } \\
\text { communicati } \\
\text { on, patient } \\
\text { education, } \\
\text { dose } \\
\text { optimization, } \\
\text { follow up. }\end{array}$ \\
\hline $\begin{array}{l}\text { Venters } \\
\text { H et al, } \\
(2010) \text {. }\end{array}$ & $\begin{array}{l}\text { Mental health } \\
\text { concerns among } \\
\text { African } \\
\text { immigrants }\end{array}$ & None & None & $\begin{array}{l}\text { Physical } \\
\text { diseases } \\
\text { neurological } \\
\text { or endocrine } \\
\text { disorder, } \\
\text { pharmacolo } \\
\text { gical } \\
\text { treatment, } \\
\text { psychoactiv } \\
\text { e drug or its } \\
\text { discontinuat } \\
\text { ion, drug } \\
\text { abuse, }\end{array}$ & $\begin{array}{l}\text { Loss of } \\
\text { appetite, } \\
\text { fatigue, } \\
\text { being } \\
\text { moody (sad, } \\
\text { empty, } \\
\text { irritable, } \\
\text { loss of } \\
\text { interest), } \\
\text { pancreatic } \\
\text { cancer in } \\
\text { elderly } \\
\text { migrants, } \\
\text { anxiety, } \\
\text { restlessness }\end{array}$ & $\begin{array}{l}\text { Diagnostic } \\
\text { and } \\
\text { Statistical } \\
\text { Manual of } \\
\text { Mental } \\
\text { Disorders } \\
\text { (DSM-5). }\end{array}$ & $\begin{array}{l}\text { Use of } \\
\text { antidepressan } \\
\text { ts alone, } \\
\text { psychotherap } \\
\text { y alone, } \\
\text { combined } \\
\text { anti- } \\
\text { depressant/ps } \\
\text { ychotherapy, } \\
\text { electroconvul } \\
\text { sive therapy, } \\
\text { transcranial } \\
\text { magnetic } \\
\text { stimulant, } \\
\text { vagal nerve } \\
\text { stimulation, } \\
\text { deep brain } \\
\text { stimulation, } \\
\text { communicati } \\
\text { on, patient } \\
\text { education, } \\
\text { dose } \\
\text { optimization, } \\
\text { follow up. }\end{array}$ \\
\hline
\end{tabular}




\begin{tabular}{|c|c|c|c|c|c|c|c|}
\hline $\begin{array}{l}\text { Baker J } \\
\text { et al. } \\
(1997)\end{array}$ & $\begin{array}{l}\text { To determine } \\
\text { migration } \\
\text { experience in } \\
\text { Africa }\end{array}$ & $\begin{array}{l}\text { All migrants } \\
\text { in Africa }\end{array}$ & Africa & None & None & None & None \\
\hline
\end{tabular}

\section{Discussions}

\section{Risk Factors for Depression among African Migrants}

Depression is still an issue of great public health significance globally and yet efficacious treatment services to improve the health of those suffering from it are readily available (WHO (2012b). Among its risk factors include migration (Flahaux \& De Haas 2016; Vroman, Knoetze $\&$ Kagee 2011; Tessie 1995). Nonetheless, natives may suffer signs that are more aggressive than migrants are (Tomita et al. 2015). This can be explained by prior exposure by natives to risk factors of depression such as the case of apartheid in South Africa. Other risk factors are generally: acculturation, duration of stay, social support systems, and lifestyle, proficiency in the native language, and literacy levels (Lassetter \& Callister (2008; Ochieng 2017). This is similar to Thela, L. et al (2017)'s findings that the length of stay determines the mental health status of the migrants. However, first-time migrants with well-established relatives tend to settle faster than those without (Jurado et al. 2017; Tomita et al 2015). Age at migration is also a key factor for depression. Children suffer greater depressive symptoms and psychotic disorders than adults (Breslau et al. 2009). However, on arrival, the elderly may be more affected, but they cope with time (Thela et al. 2017).

Other risk factors include family separation, marital status, economic status, migrant's experiences, expectation and post-traumatic stress (Cassidy 2005; Thela et al. 2017). Africans live in extended family settings and identify with communities and several generations, therefore, living in a new setting without close relatives to offer holistic support can be very stressful resulting in depression (Issack 2015). Discrimination by natives though is not associated with depression but rather post-migration factors mostly among involuntary migrants (Thela et al. 2017; Van Der Wurff et al. 2004). These findings are relatively similar to those of (Idemudia et al. 2013), which show post-migration total stressors are significant predictors at $\mathrm{P}<0.001$, post- migration sexual abuse at $\mathrm{P}<0.003$, and post-poverty at $\mathrm{P}<0.001$. However, this study was done among refugees hence such risk factors may not be common among voluntary migrants. The residential area after migration also affects mental health; urban slum residents suffer more stressors than urban dwellers (Ohaeri 2016).

\section{Signs and Symptoms of Depression among Migrants}

A study done in South Africa by Idemudia et al. (2013) identified anxiety, insomnia, and social dysfunction as common symptoms and signs of depression among both voluntary and involuntary. These symptoms were also reported by WHO (2012b) \& WHO (2012a). However, resistant and severe cases present with Psychotic Major Depression (PMD) that is characterized by chronicity, severe illness, and impairment (Venters et al 2010). The elderly migrants are more likely to have their health deteriorate at a faster rate than natives of the same age are but this is dependent on their marital status, socio-economic status and risky behaviors such as smoking and alcohol consumption (Reus-Pons. Et al 2018). 


\section{Coping Strategies for Depression among African Migrants}

Most migrants are underserved and reluctant to seek those services. Most of them cope through the silence in fear of being labeled and considered mad (Bhugra 2004, Issack 2015; Newbold \& Danford 2003). Consequently, for migrants to cope with depression, family support is important, especially among first-generation migrants. This can aid in the settlement process and reference to jobs and social services. Stressful situations within the environment can be avoided through psychosocial and spiritual support as well as paying attention to emotions (Lazarus \& Folkman 1984). Finally, all interventions should be culturally accepted, relevant and aiming to mobilize screen, and create awareness of signs and symptoms of mental disorders, referral systems, availability and accessibility of treatment services [Flahaux \& De Haas 2016; Venters et al 2010) as well as addressing risk factors (Jurado et al. 2017).

\section{Conclusion}

Depression is a common scenario among migrants whether voluntary or involuntary but screening programs targeting voluntary migrants are very rare in most African settings. Besides, efficacious treatment services are readily available but most migrants are underserved and reluctant to seek those services. Thus, culturally relevant and appropriate approaches targeting voluntary migrants can minimize the effect of depressive symptoms.

\section{Acknowledgment}

The authors with deep gratitude would like to acknowledge support by PubMed, Google Scholar databases, African Journals Online and International Organizations such as Food and Agriculture Organization (FAO), which provided necessary information for this write-up.

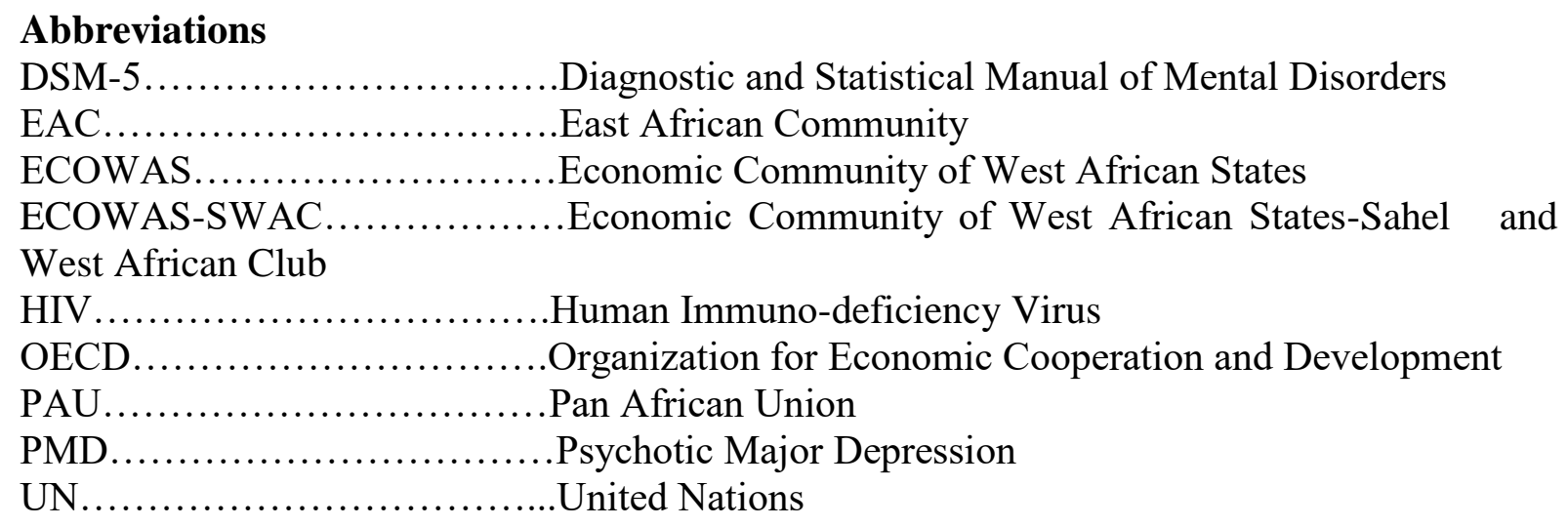

\section{References}

Adepoju, A. (2008). The linkage between internal and international migration: The African situation. International Social Sciences Journal. 50 (157): 387-389 Doi.10.1111/14682451.00151

Australian Institute of International Affairs (2017). Migration trends in the Middle East and North Africa. 2017. CAN 0000045170.

Baker J, Aida AT (1997). The migration experience in Africa. The International Journal of African Historical Studies. Doi 10.2307/220597

Bhugra D, Ayonrinde, O (2004). Depression in migrants and ethnic minorities. Advances in Psychiatric Treatment. 10 (1): 13-17. Doi.10.1192/apt.10.1.13 
Breslau J, Borges G, Hagar Y, Tachredi D, Gilman S (2009). Immigration to the USA and risk factors for mood and anxiety deity disorders: Variation by origin and age at immigration. Psychol. Med 39 (7): 117-27 Doi: 10.1017/S0033291708004698.

Carballo M, Nerukar A (2001) Migration, refugees and health risks. Conference Panel Summaries. International Center for Migration and Health Vernier, Switzerland. Emerging Infectious Diseases. 7 (3 Suppl): 556-560

Cassidy R (2005). Involuntary and voluntary migration estimates. The U.S Census Bureau

Chen AW, Kazanjian A (2005). Rate of mental health services utilization by Chinese immigrants in British Columbia. Can J Public Health. 96 (1): 49-51 Doi.org/10.1007/BF03404017

Close C, Kouvonen A, Bosqui T, Patel K, O'Reilly D, Donnelly M (2016). The Mental and wellbeing of first-generation migrants. A systematic narrative review of reviews. Globalization and Health. 12 (1):47 Doi: 10.1186/s12992-016-0187-3

Critical Appraisal Programme (2010). Qualitative appraisal checklist. https://www.casp_uk.net/wp-.pdf.

Earlise CW, Sherril LS, David P (2001). A qualitative study of depression among black African immigrant women: "It is just madness". University of Wisconsin- Madison.

ECOWAS-SWAC/OECD (2006). Migration. Atlas on regional integration in West Africa. Population series.

Flahaux ML, De Haas H (2016). African migration: Trends \& patterns. Comparative Migration Studies. 4:1 Doi.10.1186/s40878-015-0015-6

Food and Agriculture Organisation of the United Nations (FAO) (2007). Evidence on internal and international migration patterns in selected African Countries. A Joint Product of FAOs Statistics Division and Social Policies and Rural Institutional Division. FAO. $17468 \mathrm{EN} / 1 / 06.07$

Idemudia ES, Williams JK, Madu SN, Wyatt GE (2013). Trauma exposures and post-traumatic stress among Zimbabwean refugees in South Africa. Life Sci J. 25; 10 (3). pii: 349.

Issack S (2015). Mental health. Help-seeking behaviour: African Migrants experience. Queen's University Kingston, Ontario, Canada.

Jurado D, Alarcon DR, Martinez-Ortega MJ, Mendieta-Marichal Y, Gutierrez-Rojas L, Gurpegui M (2017). Factors associated with psychological distress or common mental disorders in migrant populations across the world. Rev Psiquiatr Salud Ment. 10(1):4558 Doi: 10.1016/j.rpsm.2016.04.004

Kesser RC \& Marilyn E (1982). Marital Status and depression: The importance of coping Resources. Soc Forces. 61(2): 484-507 DOI: 10.2307/2578238

Lassetter HJ, Callister CL (2008). The impact of migration on the health migrants in western societies. A review of the literature. Journal of Transcultural Nursing. 2008; 20 (1): 93104 doi: $10.1177 / 1043659608325841$.

Latif Z (2014). Better Health Briefing 31. The maternal mental health of migrant women. A race Equality Foundation Briefing Paper.

Lazarus SR \& Folkman S (1984). Stress, appraisal, Coping. Springer.

Maharaj V, Tomita A, Thela L, Mhlongo M, Burns JK (2017). Food insecurity and risk of depression among refugees and immigrants in South Africa. Journal of Immigration Minor Health. 19 (3): 633-637 Doi: 10.1007/s10903-016-0370-x

Maina G, Mauri M, Rossi A (2016). Anxiety and Depression. Journal of Psychopathology. 22: 236- 250

Martin FS (2001). Global migration trends and asylum. New issues in refugee research. Working paper No. 41 
McCann TV, Mugavin J, Renzaho A, Lubman DI (2016). Sub-Saharan African migrant youths' help-seeking barriers and facilitation for mental health and substance use problems: A qualitative study. BMC Psychiatry. 16: 275 Doi: 10.1186/s12888-016-0984-5

Moher D, Liberati A, Tetzlaff, Atman DG (2009). The PRISMA group. Preferred Reporting Items for Systematic Review and Meta-Analysis: The PRISMA statement. Plos Med. 6:e1000097

Newbold KB, Danford J (2003). Health status and Canadian's migrant population. Social Sciences Medicine. 57 (10): 1981-1995.

Ochieng MNB (2017). Black African migrants: Barriers with accessing and utilizing health promotion services in UK. European Journal of Public Health. 23(2):265-9. Doi: 10.1093/eurpub/cks063

Ohaeri JU (2016). Coping with stress of urban living in the urban millennium: Oyo Binitie and Current Perspectives. Nigerian Journal of Psychiatry. 14 (1)

Pannetier J, Lert F, Roustide MJ, Desgrees du Lou A (2017). Mental health of sub-Saharan African migrants: The gendered role of migration paths and transnational ties. Elsevier. SSM- Population Health 3. 549 - 557 Doi: 10.1016/j.ssmph.2017.06.003

Reus-Pons M, Mulder HC, Kibele UBE, Janssen F (2018). Differences in the health transition patterns of migrants and non-migrants aged 50 and older in Southern \& Western Europe (2004-2015). BMC Medicine. 16(1):57. Doi: 10.1186/s12916-018-1044-4

Rogge JR (2013). Urban Refugees in Africa. Some changing dimensions to African Refugees Problem, with special reference to Sudan. Migration World Magazine. 14 (4): 7-13

Schmied V, Black E, Naidoo N, Dahlen GH (2017). Migrant women's experience, meaning and ways of dealing with postnatal depression: A meta-ethnographic study. PLoSOne. 15; 12(3):e0172385. Doi: 10.1371/journal.pone.0172385.

Silviera ER, Ebrahim S (1998). Social determinants of psychiatric morbidity and wellbeing in migrant elders and whites in East London. Int. J Geriatr Psychiatry. 13 (11):810-12.

Tessie K (1995). The challenge of immigration policy in the new South Africa. Indiana Journal of Global Legal Studies. 14. Vol 3. (1): 255-60

Thela L, Tomita A, Maharaj V, Mhlongo M, \& Burns JK (2017). Counting the cost of Afrophobia: Post-Migration adaption and Mental Health challenges of African Refugees in South Africa. Transcult Psychiatry. 54 (5-6):715-732. Doi: $10.1177 / 1363461517745472$.

Tomita A, Charlotte A, Labys A, Jonathan KB (2015). The relationship between immigration and depression in South Africa: Evidence from the first South African national income dynamic study. Journal of Immigrants and Minority Health 16 (6):1062-8. Doi: 10.1007/s10903-014-9987-9.

United Nations (2017). International Migration Report. Economics and Social Affairs. ST/ESA/SER.A/403

Van Der Wurff F.B, Beekman AT, Dijkshoorn H, Spijker JA, Smits CH, Stek ML, Verhoeff A (2004). Prevalence and risk factors for depression in elderly Turkish and Moroccan migrants in the Netherlands. Journal of Affect Disorder. 2004; 83 (1): 33-41 Doi:10.1016/j.jad.2004.04.009

Venters H, Adekugbe O, Massaquoi J, Nadeau C, Saul J, Gany F (2010). Mental health concerns among African Immigrants. J Immigrant Minority Health. 13(4), 795-797 Doi.10.1007/s10903-010-9357-1

Viruell-Fuentes AE, Miranda YP, Abdulrahim S (2011). More than culture: Social racism, intersectionality theory, and immigrant health. Social Sciences and Medicine. 2012; 75: 2099-2106. Doi: 10.1016/j.socscimed. 12.037 
Viruell-Fuentes, Schulz (2009). Toward a Dynamic Conceptualization of Social Ties and Context: Implications for Understanding Immigrant and Latino Health. Am J. Public health. 2009; 99 (12): 2167- 2175 Doi: 10.2105/AJPH.2008.158956

Vroman LS, Knoetze K, Kagee A (2011). The presence of Xenophobia in South Africa. Am J Orthopsychiatry. 81 (1): 90-3 Doi: 10.1111/j.1939-0025.2010.01075.x

WHO (2012a) Sixty-fifth world health assembly. World Health Organization 2012a

WHO (2012b) Depression. A global public health concern. WHO Department Mental Health and Substance Abuse. World Health Organisation.

Williams RD, Gonzalez MH., Neighbours H, Nesse RM., Albelson MJ, Sweetman J, Jackson SJ (2007). Prevalence and distribution of major depressive disorders in African Americans, Caribbean Blacks, and Non-Hispanic whites: Results from National Survey of American Life. Arch Gen Psychiatry. 64: 305-315 Doi:10.1001/archpsyc.64.3.305 